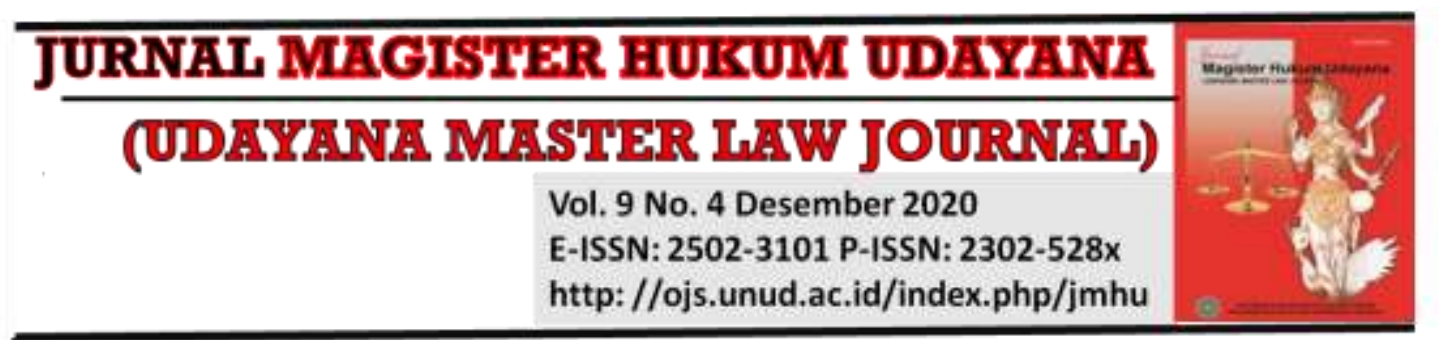

\title{
Pengaturan Bidang Pengawasan dalam Rangka Memperkuat Hak Perlindungan Varietas Tanaman
}

\author{
Kadek Sutrisna Dewi', I Wayan Wiryawan²
}

1 PT. Casia Karunia Jaya, E-mail: sutrisnadewi865@gmail.com

${ }^{2}$ Fakultas Hukum Universitas Udayana, E-mail: wayan_wiryawan@yahoo.com

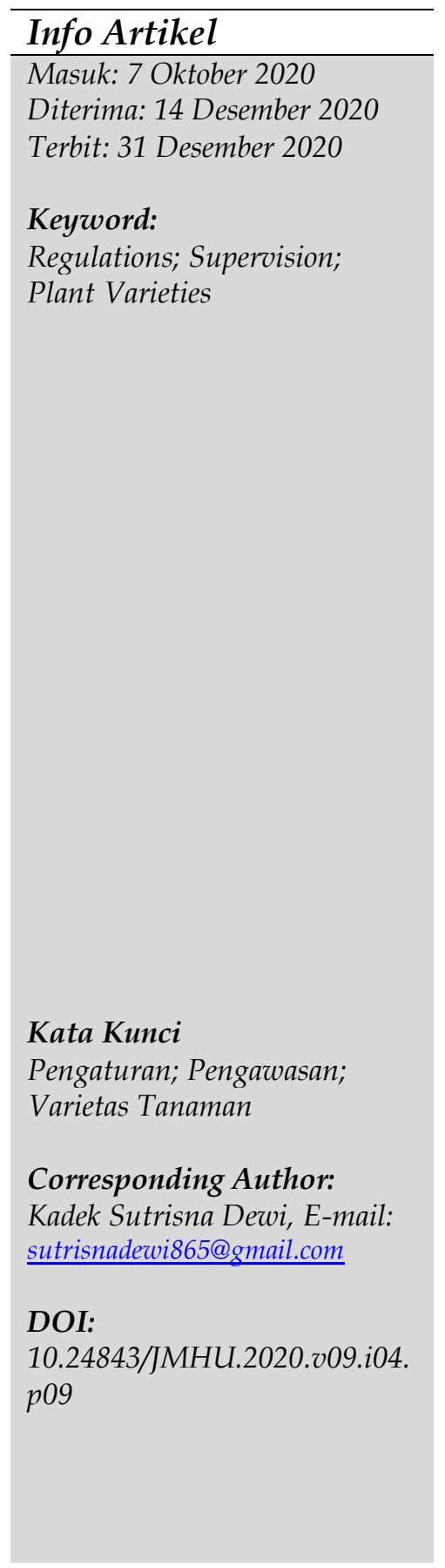

\begin{abstract}
The development of globalization in era of free market economy has caused many problems to protection of plant varieties. Therefore, it's deemed necessary to make specific arrangements of supervision in the protection of plant varieties in Indonesia. The writing of this article aims to examine the regulatory aspects of supervision in plant varieties and the importance of regulating of supervision in plant varieties. This article uses normative legal research methods, which research the laws and regulations that have legal problems. The results of the study shows that the aspects of supervision in regulations relating to the protection of plant varieties haven't been regulated in detail and concretely. The absence of regulations regarding the supervision, causes supervision can't be carried out optimally, and the supervision can't be said to be legal according to law. Supervision is very important to regulated, because it carried out with the aim of preventing the emergence of fraudulent practices such as deception, monopolistic practices, and other activities that have a negative impact on the economy in terms of protecting plant varieties. Juridical arrangements regarding supervision related to the protection of plant varieties need to be carried out to provide a foundation for the relevant agencies in carrying out their supervisory duties as well as to increase protection or provide legal certainty for parties holding the rights to protect plant varieties. In addition, it's also to prevent fraudulent acts committed by irresponsible persons.
\end{abstract}


belum diatur secara mendetail dan konkrit. Ketiaadan pengaturan mengenai pengawasan terkait perlindungan varietas tanaman menyebabkan pengawasan tidak dapat dilaksanakan secara maksimal, serta pengawasan yang dilakukan oleh instansi terkait tidak dapat dikatakan sah menurut hukum. Pengawasan pada dasarnya merupakan hal sangat penting untuk diatur, karena pengawasan dilaksanakan dengan maksud untuk mencegah timbulnya praktik kecurangan seperti penipuan, praktik monopoli, maupun kegiatan lain yang menimbulkan dampak negatif terhadap perekonomian dalam hal perlindungan varietas tanaman. Pengaturan secara yuridis mengenai pengawasan terkait perlidungan varietas tanaman perlu dilakukan untuk memberikan landasan berpijak kepada instansi terkait dalam melaksanakan tugasnya terkait pengawasan sekaligus guna meningkatkan perlindungan maupun memberikan jaminan kepastian hukum bagi pihak yang memegang hak perlindungan varietas tanaman. Selain itu juga untuk mencegah terjadinya tindakan kecurangan yang dilakukan oleh oknum-oknum yang tidak bertanggungjawab.

\section{Pendahuluan}

Indonesia ialah negara yang sedang berkembang dan saat ini sedang giatnya melakukan upaya perkembangan ilmu pengetahuan maupun teknologi. Pengembangan teknologi tersebut, dilakukan dalam berbagai aspek kehidupan, yang salah satu di dalamnya termasuk dalam bidang teknologi pertanian. Dewasa ini, teknologi pertanian di Indonesia semakin berkembang pesat seiring dengan kemajuan ilmu pengetahuan. Perkembangan teknologi pertanian ini tidak terlepas dari peran pemerintah, masyarakat, perguruan tinggi, bahkan perusahaan swasta.

Pengembangan teknologi pertanian memiliki peranan penting dalam keberhasilan produktivitas usaha tani yang dihasilkan, serta meningkatkan kualitas produk pertanian. ${ }^{1}$ Untuk mewujudkan suatu produk pertanian dengan kualitas yang bagus, perlu diterapkan berbagai upaya berbasis pengetahuan dan teknologi seperti teknik persilangan. Penerapan teknik persilangan ini dalam berbagai varietas tanaman dapat menghasilkan jenis varietas baru yang memiliki keunggulan dan kemanfaatan yang lebih baik dari tanaman sebelumnya. ${ }^{2}$ Teknik persilangan dengan menghasilkan tanaman baru ini juga disebut sebagai pemuliaan tanaman.

Pemuliaan tanaman membutuhkan suatu kemampuan intelektual agar dapat menghasilkan suatu produk yang berkualitas. ${ }^{3}$ Oleh karena itulah varietas tanaman tersebut harus memperoleh perlindungan hukum kekayaan intelektual, karena tidak semua orang dapat mempekerjakan intelektualnya. Perlindungan hukum terhadap pemulia tanaman diberikan melalui sertifikat perlindungan varietas tanaman yang diperoleh melalui suatu pendaftaran.

${ }^{1}$ Imaniyati, N. S. (2015). Perlindungan HKI Sebagai Upaya Pemenuhan Hak Atas IPTEK, Budaya dan Seni. Media Hukum, 17(1).

2 Azrai, M. (2006). Sinergi teknologi marka molekuler dalam pemuliaan tanaman jagung. Jurnal Litbang Pertanian, 25(3), 81-89.

3 Soedjono, S. (2003). Aplikasi mutasi induksi dan variasi somaklonal dalam pemuliaan tanaman. Jurnal Litbang Pertanian, 22(2), 70-78. 
Perlindungan varietas tanaman memberikan manfaat terhadap peningkatan nilai jual suatu barang atau produk. Perlindungan varietas tanaman juga mampu mendorong suatu produk untuk dapat bersaing dalam kancah internasional. Selain memiliki manfaat dalam menambah nilai ekonomi pada suatu barang, potensi ekonomi perlindungan varietas tanaman juga dapat memberi suatu manfaat dalam memacu peningkatan kesejahteraan maupun memberi keuntungan bagi masyarakat yang berperan sebagai pemulia tanaman. Perlindungan varietas tanaman memberikan manfaat dalam meningkatkan jumlah serta laju varietas unggulan suatu tanaman yang mampu bersaing dalam perdagangan. Kemudian juga dapat meningkatkan berbagai varietas tanaman yang mampu bersaing dalam pembenihan tanaman, mengurangi penggunaan bahan kimia, serta pemanfaatan lahan yang lebih efisien. ${ }^{4}$

Pada dasarnya, perlindungan varietas tanaman merupakan bentuk perlindungan yang bersifat khusus dari pemerintah atau negara negara kepada varietas tanaman dengan karakteristik yang berbeda dari suatu spesies maupun jenis tanaman yang sama sebagai sebuah hasil kekayaan intelektual. Spesies atau jenis tanaman yang sama tersebut merupakan hasil dari kegiatan pemuliaan tanaman. Pemuliaan tanaman tersebut dilakukan melalui kegiatan meneliti dan menguji atau kegiatan yang dilakukan untuk menemukan dan mengembangkan suatu varietas, dengan memanfaatkan metode baku guna mendapatkan hasil varietas tanaman baru yang dapat dipertahankan kemurnian benihnya, sehingga tidak mengalami perubahan pada saat diperbanyak. ${ }^{5}$ Perlindungan terhadap hak pemulia tanaman telah diakomodir dalam peraturan perundang-undangan, salah satunya dalam Undang-Undang Perlindungan Varietas Tanaman yaitu Undang-Undang Nomor 29 Tahun 2000.

Banyaknya manfaat yang diperoleh dari adanya perlindungan hak kekayaan intelektual tersebut, tentunya mendorong banyak pihak yang ingin mendaftarkan produknya. Akan tetapi, dibalik berbagai dampak positif yang ditimbulkan dari adanya perlindungan varietas tanaman, dalam peraturan perundang-undangan terkait perlindungan varietas tanaman belum diatur mengenai aspek pengawasannya. Hal tersebut tentu saja menimbulkan dampak negatif terutama dalam kegiatan komersialisasi produk yang telah mendapatkan sertifikasi PVT. Dengan tidak adanya aspek pengawasan dalam perlindungan varietas tanaman dapat menimbulkan berbagai kecurangan seperti penipuan, praktik monopoli, maupun kegiatan lain yang menimbulkan dampak negatif terhadap perlindungan kekayaan intelektual di Indonesia.

Karena ketiadaan pengaturan yang berakibat pada tidak adanya kepastian hukum dalam pengawasan perlindungan varietas tanaman, maka dianggap penting melakukan penelitian terhadap aspek pengawasan dalam perlindungan varietas tanaman, dengan mengkaji permasalahan tersebut dalam sebuah artikel ilmiah yang berjudul "Pengaturan Bidang Pengawasan dalam Rangka Memperkuat Hak Perlindungaan Varietas Tanaman". Penulisan artikel ini memiliki 2 (dua) tujuan penting. Pertama, melalui artikel ini penulis hendak mengkaji mengenai pengaturan aspek pengawasaan dalam menjamin perlindungan varietas tanaman. Kedua, melalui

\footnotetext{
${ }^{4}$ Purwandoko, P. H., \& Imanullah, M. N. (2013). Perlindungan Varietas Tanaman Sebagai Salah Satu Bentuk Perlindungan Hak Ekonomi Para Pemulia Tanaman Menuju Ketahanan Pangan Nasional. Yustisia Jurnal Hukum, 2(3)., 84. DOI: https://doi.org/10.20961/yustisia.v2i3.10162.

${ }^{5}$ Dewi, I. S., \& Purwoko, B. S. (2001). Kultur antera untuk mendukung program pemuliaan tanaman padi. Jurnal Agronomi Indonesia (Indonesian Journal of Agronomy), 29(2).
} 
artikel ini penulis juga hendak mengkaji arti penting pengawasan tersebut dalam menjamin perlindungan varietas tanaman di Indonesia.

Pengaturan terhadap aspek pengawasan dalam perlindungan varietas tanaman ini sejatinya memang perlu untuk dikaji lebih lanjut, agar terdapat perlindungan yang tegas demi tterciptanya varietas unggul tanaman yang dapat memberikan dampak besar bagi kemajuan ekonomi di masyarakat. Mengingat begitu pentingnya perlindungan varietas tanaman ini, banyak penelitian yang telah dilakukan, dengan berbagai sumbangan pemikiran guna menciptakan perkembangan dalam perlindungan varietas tanaman. Salah satunya yaitu tulisan yang berjudul "Perlindungan Varietas Tanaman Sebagai Salah Satu Bentuk Perlindungan Hak Ekonomi Para Pemulia Tanaman Menuju Ketahanan Pangan Nasional". Artikel tersebut pada intinya membahas mengenai kontribusi dari peraturan dalam bidang perlindungan varietas tanaman dalam melindungi hak ekonomi pemulia tanaman demi tercapainya ketahanan pangan di Indonesia. Berdasarkan penelitian yang dilakukan dalam artikel tersebut, dapat diketahui peraturan dalam bidang perlindungan varietas tanaman belum mampu mendorong pemulia tanaman menghasilkan bibit unggul dikarenakan belum mampu melindungi hak ekonomi pemulia tanaman.

Selain itu, terdapat pula artikel yang berjudul "Perlindungan Hukum Terhadap Varietas Tanaman dalam Memberikan Kepastian Hukum Kepada Pemulia Tanaman". Pada intinya, penelitian tersebut membahas mengenai prosedur memperoleh perlindungan hukum serta pentingnya kepastian hukum bagi pemulia tanaman berkaitan dengan perlindungan varietas tanaman. Berdasarkan penelitian tersebut, diperoleh hasil bahwa perlindungan hukum diberikan melalui proses pendaftaran. Perlindungan hukum bagi pemulia tanaman dapat berupa perlindungan preventif serta represif.

Mengacu pada penelitian yang dilakukan dalam bidang perlindungan varietas tanaman tersebut, penulisan artikel yang berjudul Pengaturan Bidang Pengawasan dalam Rangka Memperkuat Hak Perlindungaan Varietas Tanaman ini dapat dikatakan baru dan belum ada yang mengkaji sebelumnya, karena membahas permasalahan yang berbeda dengan artikel lainnya. Sehingga artikel ini merupakan sumbangan pemikiran yang mempunyai kontribusi baru dalam kegiatan perlindungan varietas tanaman di Indonesia.

\section{Metode Penelitian}

Penulisan artikel ilmiah ini menggunakan metode penelitian hukum normatif. Dalam penelitian hukum normatif ini, fokus kajian dan bahasan terdapat pada kekosongan norma dalam pengawasan terhadap hak perlindungan varietas tanaman. Adapun metode pendekatan yang penulis gunakan dalam penulisan artikel ilmiah ini yaitu pendekatan perundang-undangan atau yang sering disebut the statue approach, serta pendekatan analisis konseptual (the analytical $\mathcal{E}$ conceptual approach). Kemudian, teknik penelusuran bahan hukum yang digunakan dalam penulisan artikel ini yaitu teknik studi dokumen dengan mengkaji peraturan perundang-undangan dalam bidang perlindungan varietas tanaman, serta analisis bahan hukum hukum yang digunakan ialah teknik deskripsi dan analisis kualitatif. 


\section{Hasil dan Pembahasan}

\subsection{Pengaturan Aspek Pengawasan Terkait Perlindungan Varietas Tanaman di Indonesia}

Indonesia sebagai salah satu negara yang menganut sistem hukum sipil, memiliki kecenderungan penekanan hukum dalam aspek norma atau yang sering disebut sebagai hukum tertulis yang bersifat abstrak dan konseptual. Ciri khas yang menjadi landasan dari sistem hukum sipil yaitu hukum mendapatkan atau memperoleh kekuatan mengikatnya apabila telah diwujudkan dalam sebuah peraturan perundangundangan, yang memiliki susunan sitemasis dalam sebuah kodifikasi. ${ }^{6}$ Karakteristik dasar ini, dianut mengingat bahwa tujuan utama dari hukum ialah suatu kepastian hukum. Tujuan hukum ini baru dapat tercapai apabila tindakan-tindakan atau perbuatan-perbuatan hukum setiap manusia dalam pergaulan hidupnya telah diatur secara tertulis dalam sebuah peraturan perundang-undangan. Lebih dari itu, mengacu pula pada aliran positivisme dalam ajaran filsafat hukum, memang perlu dilakukan pemisahan secara tegas antara hukum dan moral, atau dengan kata lain antara das sein dan das sollen. Apabila berkaca pada pandangan positivis, maka dapat diketahui bahwa tiada hukum yang lain, kecuali apa yang diperintahkan oleh penguasa. Bahkan, lebih tegasnya lagi, pada bagian lain dari ajaran positivisme hukum yang sering dikenal sebagai Legisme, memiliki pendapat bahwa hukum tersebut identik sebagai undang-undang. ${ }^{7}$ Positivisme hukum dalam hal ini tiada lain bertujuan untuk dapat terciptanya kepastian hukum dalam masyarakat. Karena aspek utama dalam pelaksanaan hukum dalam masyarakat ialah adanya kepastian hukum yang merupakan salah satu tujuan dari hukum itu sendiri.

Mengacu pada sistem hukum sipil yang dianut oleh Indonesia, serta mengacu pada pandangan positivisme yang sejalan dengan pemikiran civil law, maka merupakan suatu keharusan bahwa setiap kebijakan yang hendak diambil harus tertuang dalam peraturan perundang-undangan secara tertulis. Oleh karena itulah aspek pengawasan dalam perlindungan varietas tanaman sebagai bagian dari suatu kewenangan pemerintah harus ditentukan dengan tegas dalam sebuah peraturan perundangundangan yang ada di Indonesia.

Ketentuan dalam Undang-Undang Perlindungan Varietas Tanaman yaitu UndangUndang Nomor 29 Tahun 2000 yang memerlukan adanya aspek pengawasan yaitu ketentuan mengenai pencabutan hak perlindungan varietas tanaman, khususnya dalam ketentuan Pasal 60 ayat (2) Undang-Undang Perlindungan Varietas Tanaman yang menentukan bahwa:

“Hak PVT dicabut berdasarkan alasan:

a. pemegang hak PVT tidak memenuhi kewajiban membayar biaya tahunan dalam jangka waktu enam bulan;

\footnotetext{
${ }^{6}$ Nurhardianto, F. (2015). Sistem Hukum dan Posisi Hukum Indonesia. Jurnal Tapis: Jurnal Teropong Aspirasi Politik Islam, 11(1), 33-44. DOI: https:// doi.org/10.24042/tps.v11i1.840

7 Darmodiharjo, D dan Shidarta. (2014). Pokok-Pokok Filsafat Hukum. Jakarta: PT Gramedia Pustaka Utama, h. 113.
} 
b. syarat/ciri-ciri dari varietas yang dilindungi sudah berubah atau tidak sesuai lagi dengan ketentuan dalam Pasal 2;

c. pemegang hak PVT tidak mampu menyediakan dan menyiapkan contoh benih varietas yang telah mendapatkan hak PVT;

d. pemegang hak PVT tidak menyediakan benih varietas yang telah mendapatkan hak PVT; atau

e. pemegang hak PVT mengajukan permohonan pencabutan hak PVT-nya, serta alasannya secara tertulis kepada Kantor PVT".

Berdasarkan ketentuan Pasal tersebut, aspek pengawasan yang dimaksud erat kaitannya dengan pengawasan terhadap tetap terjaganya ciri-ciri varietas yang memperoleh perlindungan varietas tanaman. Selain itu, adanya pengawasan dalam hal ini juga ditujukan agar para pemegang hak perlindungan varietas tanaman melaksanakan kewajibannya dalam hal pemenuhan kewajiban pembayaran serta menyediakan contoh benih dari varietas tanaman yang dilindungi. Hal ini dimaksudkan tiada lain agar tetap terjaganya kualitas produk, serta pendapatan negara melalui pembayaran kewajiban perlindungan varietas tanaman dapat dikelola dengan baik oleh negara. Sehingga melalui pendapatan negara bukan pajak ini, dapat membantu memperkuat perekonomian di Indonesia.

Pengawasan dalam kegiatan perlindungan varietas tanaman merupakan aspek yang sangat penting dalam perlindungan varietas tanaman. Sama halnya dengan pengawasan yang terdapat dalam indikasi geografis. Pada dasarnya, perlindungan varietas tanaman serta indikasi geografis merupakan hal yang tidak jauh berbeda. Keduanya merupakan bagian dari perlindungan hak kekayaan intelektual. Indikasi geografis pada hakikatnya ialah sebuah tanda yang menunjukkan atau mengidentifikasikan suatu wilayah tertentu, atau kawasan maupun daerah yang sebagai asal usul suatu barang, dimana faktor geografis sangat menentukan reputasi, kualitas, maupun karakteristik dari barang yang bersangkutan. ${ }^{8}$ Kemudian, perlindungan varietas tanaman pada intinya merupakan suatu bentuk perlindungan dalam bidang kekayaan intelektual, yang diberikan oleh negara atau penguasa kepada pihak yang melakukan pemuliaan tanaman atau yang sering disebut sebagai pemegang hak PVT untuk secara penuh memegang kendali atas bahan untuk memperbanyak varietas tanaman yang mencakup benih, anakan, stek, maupun jaringan sebagai perkembangbiakan, serta memegang kendali pula terhadap material yang dipanen berdasarkan jangka waktu yang telah ditentukan. ${ }^{9}$ Pada dasarnya, perlindungan terhadap varietas tanaman merupakan bentuk perlindungan melalui sistem sui generis yang dapat diartikan bahwa perlindungan terhadap varietas tanaman dilakukan diserahkan kepada masing-masing negara sesuai dengan kebutuhan. ${ }^{10}$

Berdasarkan penjelasan tersebut, dapat dipahami bahwa pada hakikatnya indikasi geografis serta perlindungan varietas tanaman merupakan perlindungan terhadap

\footnotetext{
${ }^{8}$ Rahmatullah, I. (2014). Perlindungan indikasi geografis dalam hak kekayaan intelektual (HKI) melalui ratifikasi perjanjian Lisabon. Jurnal Cita Hukum,2(2). DOI: https://doi.org/10.15408/jch.v1i2.1470 .

9 Simanjuntak,F. (2013). Perlindungan Hukum Pada Pemberian Lisensi Bagi Pemulia Varietas Tanaman. LAW REFORM, 9(1), h. 27-52. DOI: https://doi.org/10.14710/lr.v9i1.12433.

${ }^{10}$ Purwandoko, P. H., \& Imanullah, M. N. Op.cit., h. 86.
} 
suatu objek dalam bidang hak kekayaan intelektual. Dalam perlindungan indikasi geografis yang menjadi objek perlindungan ialah hasil pertanian. Begitupula dalam perlindungan varietas tanaman, yang menjadi objeknya adalah hasil pertanian. Perbedaan dalam perlindungan indikasi geografis dan perlindungan varietas tanaman yaitu hasil pertanian yang dilindungi dalam indikasi geografis ialah hasil pertanian yang sangat dipengaruhi oleh geografis suatu wilayah. Sedangkan perlindungan terhadap varietas tanaman dipengaruhi oleh hasil intelektual pemulia tanaman dalam menciptakan suatu benih baru yang belum pernah diciptakan, serta belum pernah memperoleh perlindungan varietas tanaman.

Perlindungan varietas tanaman serta indikasi geografis memiliki sistem perlindungan yag tidak jauh berbeda. Perlindungan terhadap varietas tanaman serta perlindungan terhadap indikasi geografis akan tetap berlangsung apabila reputasi, kualitas, serta karakteristik dari produk yang dilindungi tetap ada dan tidak berubah. Oleh karena adanya sistem perlindungan yang demikian, maka perlu dilakukan pengawasan terhadap produk yang memperoleh perlindungan, untuk menjamin terjaganya kualitas, reputasi serta karakteristik yang memperoleh perlindungan.

Pada dasarnya, indikasi geografis yang memiliki sistem perlindungan hampir sama dengan perlindungan varietas tanaman telah mengatur mengenai aspek pengawasan. Hal ini ditujukan agar tetap terjaganya kualitas, reputasi, serta karakteristik produk tetap terjaga. Aspek pengawasan dalam perlindungan terhadap indikasi geografis, telah diatur di dalam Undang-Undang Indikasi Geografis, yakni Undang-Undang Nomor 20 Tahun 2016, tepatnya dalam Pasal 71. Pada intinya pasal tersebut mengatur bahwa pengawasan terhadap kekayaan intelektual dalam bidang indikasi geografis, dilakukan oleh pemerintah pusat dan daerah menururt kewenangannya. Pengawasan tersebut dilakukan tiada lain dengan tujuan untuk melindungi hak ekskusif indikasi geografis, yakni tetap terjaganya karakteristik, reputasi maupun kualitas dari produk yang memperoleh perlindungan indikasi geografis. Selain itu, pengawasan terhadap indikasi geografis dilakukan untuk mencegah indikasi geografis digunakan secara tidak sah. Ketentuan sebagaimana diatur dalam pasal tersebut mengisyaratkan betapa pentingnya aspek pengawasan dalam bidang hak kekayaan intelektual, terutama yang berkaitan dengan hasil pertanian. Hal tersebut ditujukan agar tetap terjaminnya kualitas produk yang diperdagangkan.

Meskipun pengaturan mengenai aspek pengawasan dalam perlindungan varietas tanaman sangat diperlukan, akan tetapi sampai saat ini Undang-Undang Perlindungan Varietas Tanaman yang sudah berlaku hampir 20 tahun tersebut belum mengatur mengenai aspek pengawasan di dalamnya. Hal tersebut mengartikan bahwa tidak adanya landasan yuridis yang tegas dan jelas dalam rangka melakukan pengawasan terhadap suatu Perlindungan Varietas Tanaman. Perlu diketahui pula, pengawasan dalam kegiatan perlindungan varietas tanaman merupakan aspek yang sangat penting dalam memperkuat perekonomian Indonesia. Hal tersebut senada dengan Economic Growth Stimulus Theory, di mana teori ini berpandangan bahwa hak milik atas suatu jenis Kekayaan Intelektual pada dasarnya merupakan suatu sarana yang dapat digunakan sebagai titik acuan untuk mendorong terjadinya pengembangan ekonomi di masyarakat. Apabila merujuk pada teori tersebut, sehubungan dengan tidak diaturnya secara tegas dan jelas mengenai aspek pengawasan dalam rangka Perlindungan Varietas Tanaman, maka keadaan demikian dapat dipastikan bahwa secara otomatis dapat menyebabkan terhambatnya pengembangan ekonomi di 
masyarakat. Agar kedepannya mampu mewujudkan pengembangan ekonomi secara maksimal di masyarakat, maka sudah semestinya pemerintah sebagai pemangku kepentingan yang berkewajiban dalam mengatur landasan yuridis yang tegas dan jelas terkait dengan pengawasan varietas tanaman untuk mampu membentuk suatu landasan yuridis yang dapat memberikan jiwa kepada pihak terkait dalam rangka pengawasan terhadap varietas tanaman.

Indonesia merupakan salah satu negara yang menganut konsep negara hukum, yang artinya telah diatur secara tegas di dalam konstitusi bahwa Indonesia merupakan sebuah negara hukum. Konsekwensi dianutnya konsep negara hukum oleh Indonesia adalah segala bentuk tindakan-tindakan yang dilakukan oleh pemerintah wajib didasarkan pada prinsip-prinsip hukum yang berlaku. Hal ini mengartikan bahwa segala tindakan yang dapat dilakukan oleh pemerintah adalah tindakan-tindakan yang secara tegas telah diatur dan sah dalam suatu aturan-aturan hukum berupa undangundang maupun bentuk lainnya yang memiliki kekuatan mengikat. Keadaan ini semata-mata pula menyinggung rasa kepastian hukum di masyarakat, di mana pemerintah dipandang harus mampu bertindak atas dasar peraturan yang berlaku. Hal tersebut senada dengan pandangan dari Fredrich Julius Stahl, beliau berpandangan bahwa sebuah negara baru dapat dikatakan menganut konsep negara hukum jika telah dipenuhinya unsur-unsur yang ditentukan dalam konsep negara hukum itu sendiri, salah satu unsurnya adalah pemerintahaan berasarkan peraturan yang berlaku. Unsur tersebut dapat dipandang bahwa pemerintah menjalankan roda pemerintahan wajib didasarkan pada peraturan perundang-undangan yang berlaku.

Berkaitan dengan pengaturan dalam rangka pengawasan terhadap Perlindungan Varietas Tanaman yang sampai saat ini belum adanya peraturan yang tegas, menyebabkan proses pengawasan terhadap Perlindungan Varietas Tanaman tidak terlaksana secara maksimal. Agar segala bentuk tindakan pemerintah dianggap sah menurut hukum, salah satunya dalam rangka pengawasan terhadap Perlindungan Varietas Tanaman apabila merujuk pada konsep negara hukum tersebut, maka semestinya pemerintah selaku pemangku kepentingan yang memiliki kewenangan dalam membentuk landasan yuridis berkewajiban untuk membentuk aturan-aturan yang secara tegas, jelas, serta secara nyata telah mengatur mengenai pengawasan terhadap Perlindungan Varietas Tanaman. Tindakan yang semestinya dilakukan oleh pemerintah tersebut pada dasarnya mendorong negara Indonesia melalui pemerintahnya untuk mampu menjamin tercapainya kepastian hukum di masyarakat dalam rangka pengawasan varietas tanaman dan mengarahkan kepada negara Indonesia untuk mengenal jati dirinya sebagai negara yang menganut konsep negara hukum yang kedepannya agar mampu memenuhi unsur-unsur yang melekat pada konsep negara hukum yang telah dianutnya.

Maka dari itu, pemerintah sebagai pemangku kepentingan dalam rangka memberikan kepastian hukum di masyarakat serta terjaminnya unsur dari konsep negara hukum yang telah dipilih serta dianut di Indonesia, melalui pemerintahnya wajib untuk membentuk suatu peraturan yang bersifat tegas, jelas, dan spesifiik memberikan pengaturan dalam bidang pengawasan terhadap Perlindungan Varietas Tanaman, di mana pengaturan terhadap pengawasan tersebut dimaksudkan agar setiap orang yang memiliki hak milik terhadap suatu Perlindungan Varietas Tanaman dapat mengetahui dan memahami hak yang dimilikinya, sekaligus mempertahankan hak-hak yang dimilikinya tersebut dari segala bentuk tindakan dari oknum-oknum 
yang tidak bertanggungjawab dan mengetahui dan memahami pula kewajiban yang melekat pada seseorang pemegang hak miliki yang harus dipenuhinya sebagai pemegang sah Perlindungan Varietas Tanaman. Sehingga, dengan adanya pengaturan terhadap aspek pengawasan secara maksimal terhadap varietas tanaman, maka dapat dipastikan bahwa dengan adanya varietas tanaman yang telah memperoleh perlindungan tersebut dapat mendorong timbulnya pertumbuhan ekonomi secara merata di masyarakat.

\subsection{Arti Penting Pengaturan Aspek Pengawasan Terkait Perlindungan Varietas}

\section{Tanaman dalam Penguatan Sistem Ekonomi di Indonesia}

Menurut peraturan dalam bidang perlindungan varietas tanaman, tepatnya UndangUndang Nomor 29 Tahun 2000, yang dimaksud dengan Perlindungan Varietas Tanaman pada dasarnya merupakan suatu bentuk perlindungan secara khusus yang diberikan oleh negara atau yang diwakili oleh Pemerintah dan dilakukan oleh Kantor Perlindungan Varietas Tanaman dalam pelaksanaannya, kepada suatu varietas tanaman yang telah dihasilkan oleh pemulia tanaman melalui suatu proses atau kegiatan pemuliaan tanaman. ${ }^{11}$

Mengenai pengawasan terkait perlindungan varietas tanaman pada dasarnya belum ditemukan dalam peraturan perundang-undangan. Pengawasan merupakan tindakan yang sangat penting dalam perlindungan varietas tanaman itu sendiri. Belum diaturnya mengenai pengawasan terhadap perlindungan varietas tanaman, menyebabkan varietas tanaman tersebut sangat sulit untuk diproteksi dari segala bentuk tindakan-tindakan tertentu yang dapat mengancam keberadaan dari varietas tanaman tersebut. Apabila merujuk pada teori-teori dalam perlindungan kekayaan intelektual yang dikemukakan oleh Robert M.Sherwood sebagaimana dikutip oleh Khoirul Hidayah, yaitu reward theory, recovery theory, incentive theory, risk theory, risk theory, dan economic growth stimulus theory ${ }^{12}$, maka sudah sepatutnya bidang pengawasan dalam perlindungan varietas tanaman diatur secara tegas dalam peraturan perundang-undangan. Hal ini dikarenakan teori-teori tersebut memiliki makna yang mendalam bagi perlindungan varietas tanaman. Penjelasan masingmasing teori tersebut yaitu: reward theory merupakan imbalan yang diberikan kepada penghasil karya intelektual atas hasil kreatifitasnya; recovery theory merupakan pemulihan atau penggantian kembali yang didapatkan oleh penghasil karya intelektual atas apa yang dikorbankan atau dikeluarkan; incentive theory yang menjelaskan bahwa pemberian insentif sangat diperlukan untuk memacu kreatifitas penghasil karya intelektual; risk theory yaitu sebuah teori yang menyatakan bahwa suatu karya intelektual sangat beresiko untuk ditiru oleh orang lain, sehingga sangat perlu mendapatkan perlindungan; serta economic growth stimulus theory merupakan teori yang menyatakan bahwa pertumbuhan ekonomi suatu wilayah sangat dipengaruhi oleh kemampuan pengembangan industri kreatif terutama dalam bidang

${ }^{11}$ Handoko, D. (2015). Hukum Positif mengenai Hak Kekayaan Intelektual di Indonesia. Pekanbaru: Hawa dan Ahwa, h. 14.

12 Hidayah, K. (2018). Hukum Hak Kekayaan Intelektual. Malang: Setara Press., h.8. 
kekayaan intelektual dalam menciptakan suatu usaha yang bermanfaat bagi masyarakat. ${ }^{13}$

Berdasarkan pada teori tersebut dapat dikatakan bahwa seseorang yang memiliki hak milik atas suatu varietas tanaman wajib untuk diberi perlindungan yakni dengan memberikan penghargaan, pemulihan atau penggantian, serta insentif terhadap usaha yang telah dilakukan untuk menghindari resiko adanya peniruan oleh pihak lain, sehingga apabila telah diperoleh perlindungan tersebut dapat memacu pertumbuhan ekonomi wilayah sekitarnya.

Suatu penghargaan terhadap hak ekonomi menurut teori Reward di atas tidak akan dapat bertahan lama jika penghargaan yang telah diperoleh seseorang tersebut tidak memiliki pengawasan dari pihak terkait dalam hal penggunaan hak milik suatu varietas tanaman di masyarakat. Begitupula dengan insentif yang diberikan bagi para penemu varietas tanaman, tidak akan bertahan lama, apabila pengawasan tidak dipertegas, karena insentif ini memiliki tujuan untuk memberikan perlindungan untuk menikmati hak ekonomi penghasil varietas tanaman, sehingga memacu kegiatan penelitain yang berguna bagi perkembangan varietas unggul. ${ }^{14}$ Berdasarkan pada teori tersebut, untuk menjamin suatu penghargaan serta insentif yang diperoleh oleh seseorang terhadap varietas tanamannya mampu bertahan lama, dan tidak ditiru oleh pihak lain, maka sudah sepatutnya pihak terkait mampu untuk mengatur mengenai landasan yuridis yang tegas dan jelas terkait dengan aspek pengawasan terhadap varietas tanaman di masyarakat.

Arti penting yang tersirat dalam pengaturan pengawasan tidak serta merta hanya memberi rasa aman dan nyaman kepada pemegang hak milik varietas tanaman dari segala bentuk tindakan-tindakan tertentu yang dapat mengancam keberadaan varietas tanaman yang sebelumnya telah diperoleh suatu penghargaan oleh penemu atau pencipta varietas tanaman melalui pendaftaran. Maka dapat dipastikan bahwa sangat penting adanya pengawasan yang dilakukan oleh pihak terkait untuk menjaga keutuhan dari varietas tanaman yang telah memperoleh perlindungan sebelumnya. Melalui pengawasan yang dilakukan oleh instansi yang menaungi perlindungan varietas tanaman, maka dalam hal ini instansi yang bersangkutan dapat mengetahui tindakan-tindakan yang kemungkinan terjadi dan mampu memberi ancaman serius terhadap keberadaan suatu varietas tanaman. Adapun instansi yang dimaksud adalah Kantor Perlindungan Varietas Tanaman yang merupakan organisasi di bawah naungan dari Departemen Pertanian.

Aspek pengawasan terhadap perlindungan varietas tanaman yang belum diatur secara yuridis dalam peraturan perundang-undangan menyebabkan instansi yang bersangkutan tidak memiliki landasan yuridis dalam melakukan pengawasan terhadap varietas tanaman. Pengawasan dalam hal ini yaitu berkaitan dengan pelayanan perizinan, perlindungan varietas tanaman dari peredaran benih palsu, pemalsuan pupuk, penggunaan benih yang dilindungi tanpa izin pemilik hak PVT, serta peredaran komoditas lainnya tanpa izin. Belum diaturnya aspek pengawasan

${ }^{13}$ Sawitri, D. A. D., \& Dharmawan, N. K. S. (2020) Perlindungan Transformasi Karya Cipta Lontar Dalam Bentuk Digitalisasi. Acta Comitas: Jurnal Hukum Kenotariatan, 5(2), 298-308., h.302. DOI: https://doi.org/10.24843/AC.2020.v05.i02.p08

14 Titawati T., Loilewen, A. F., \& Ardika, G. T. (2020). Perlindungan Hukum Bagi Pemulia Tanaman. Ganec Swara, 14(1), 499-505., h. 502. DOI: 10.35327/gara.v14i1.126 
tersebut menunjukkan bahwa terdapat kekosongan norma mengenai pengawasan terkait perlindungan varietas tanaman yang sekaligus mendorong terjadinya ketidakpastian hukum di masyarakat dalam rangka pengawasan terhadap varietas tanaman. Agar ketidakpastian hukum tersebut tidak berlarut-larut terjadi di masyarakat dapat merujuk pada Teori Kepastian Hukum. Berdasarkan pada Teori Kepastian Hukum yang dikemukakan oleh Utrecht, kepastian hukum pada dasarnya memiliki 2 (dua) makna, yakni adanya aturan yang bersifat umum yang diartikan bahwa setiap individu dipandang untuk mampu memahami perilaku yang boleh dan tidak boleh dilakukan, dan terkait dengan adanya rasa aman bagi setiap individu dari segala tindakan sewenang-wenang yang dilakukan oleh pemerintah, dengan melalui aturan yang bersifat unum tersebut maka individu mampu mengetahui dan memahami kewajiban yang dapat dibebankan oleh Negara kepada setiap individu. ${ }^{15}$ Akan tetapi dalam rangka pengawasan terhadap varietas tanaman belum diatur secara tegas dan jelas, tidak menutup kemungkinan masyarakat tidak mengetahui laranganlarangan yang ada, di mana keadaan ini yang dapat mendorong timbulnya tindakan pelanggaran oleh oknum-oknum yang tidak bertanggung jawab, dan tidak menutup kemungkinan pula pemerintah melakukan kesewenang-wenangan atas hak milik varietas tanaman. Apabila merujuk pada Teori Kepastian hukum tersebut, sebagai pemangku kepentingan pemerintah diharapkan mampu menjunjung tinggi kepastian hukum melalui pengaturan terkait dengan aspek pengawasan terhadap varietas tanaman secara tegas dan jelas, sehingga tindakan kesewenang-wenangan dilakukan oleh oknum-oknum tidak bertanggung jawab dapat dicegah.

Kekosongan norma pada dasarnya dapat dikaji dengan melakukan konstruksi hukum melalui analogi, rechtsverfijning dan argumentum a contrario. Adapun metode konstruksi hukum, meliputi: metode analogi, rechtsverfijning, dan argumentum a contrario. ${ }^{16}$

\section{Metode Argumentum Per Analogium (Analogi)}

Metode analogi ini, pada dasarnya ialah metode penerapan hukum atau suatu ketentuan dalam peraturan perundang-undangan yang pada intinya memiliki kesamaan keadaan yang secara eksplisitnya telah diatur dalam ketentuan hukum, akan tetapi tampilan atau perwujudannya yang menggunakan bentuk hukum lain. ${ }^{17}$

\section{Metode Argumentum a Contrario}

Metode konstruksi hukum ini pada intinya merupakan sebuah metode yang memberikan hakim kesempatan untuk melakukan penemuan hukum dengan sistem atau ungkapan pengingkaran, yang artinya apabila undang-undang telah menetapkan hal-hal tertentu untuk peristiwa-peristiwa tertentu, maka peraturan

15 Lestari, E. I., Raisah, K., \& Prabandari, A. P. (2019). Perlindungan Hukum Terhadap Varietas Tanaman Dalam Memberikan Kepastian Hukum Kepada Pemulia Tanaman. Notarius, 12(2), h, 975. 972-984. DOI: https://doi.org/10.14710/nts.v12i2.29140

16 Hadjon, P.M \& Djatmiati, T.S. (2016). Argumentasi Hukum. Yogyakarta: Gadjah Mada University Press, h. 27.

17 Juanda, E. (2017). Konstruksi Hukum dan Metode Interpretasi Hukum. Jurnal Ilmiah Galuh Justisi, 4(2), 168-180. 
tersebut terbatas pada peristiwa tertentu pula. Begitupun sebaliknya bagi peristiwa di luar dari apa yang telah ditentukan maka berlaku sebaliknya. ${ }^{18}$

3. Metode Penyempitan Hukum (Rechtsverfijning)

Metode ini memiliki fungsi untuk mempersempit ruang lingkup dari peraturan perundang-undangan. Ruang lingkup yang dimaksud dalam hal ini ialah cakupan terhadap peristiwa-peristiwa hukum yang diatur, dengan tujuan agar suatu peristiwa hukum tertentu yang bersifat terlalu abstrak, umum serta pasif, dapat dipersempit dan dikonkritkan pengaturannya. ${ }^{19}$

Melalui metode konstruksi hukum yang telah dijelaskan di atas, maka dalam hal terjadinya kekosongan hukum dalam pengaturan aspek pengawasan terkait perlindungan varietas tanaman dapat dilakukan melalui konstruksi hukum yang dimaksudkan untuk dapat membentuk landasan yuridis yang jelas dan pasti terkait dengan pengawasan terhadap perlindungan varietas tanaman. Pengaturan aspek pengawasan terkait perlindungan varietas tanaman dapat dilakukan dengan menggunakan metode konstruksi hukum metode analogi, rechtsverfijning, dan argumentum a contrario.

Ketiadaan pengawasan terhadap perlindungan varietas tanaman secara otomatis memberikan celah yang sangat luas kepada oknum-oknum tertentu untuk menggunakan varietas tanaman yang telah memperoleh perlindungan melalui pendaftaran varietas tanaman demi memenuhi kepentingannya pribadi. Apabila pengawasan terhadap varietas tanaman tidak dilakukan oleh instansi terkait dikarenakan belum diaturnya secara yuridis mengenai pengawasan terhadap varietas tanaman, maka dapat menimbulkan maraknya perbuatan-perbuatan yang melanggar hukum yang dapat mengancam eksistensi dari varietas tanaman itu sendiri. Adapun perbuatan melanggar hukum yang dapat terjadi sehubungan belum diaturnya mengenai pengawasan terhadap varietas tanaman yakni terjadinya praktik kecurangan seperti penipuan, pemalsuan, praktik monopoli, maupun kegiatan lain yang menimbulkan dampak negatif terhadap perekonomian. Salah satu kasus pelanggaran terhadap perlindungan varietas tanaman yaitu pemalsuan benih jagung PT BISI yang dilakukan oleh dua karyawan PT BISI yang bernama Dedi dan Suyoto. Pemalsuan tersebut dilakukan pula dengan memalsukan Hologram PT BISI, sehingga kedua karyawan tersebut terbukti melakukan sertifikasi liar sebab benih yang digunakan untuk ditanam kembali tersebut, diedarkan kepada pihak lain. Selain itu, terdapat pula kasus pelanggaran terhadap perlindungan varietas tanaman yang dilakukan oleh Muhammad Mintoro, yaitu dengan sengaja menjual atau memperdagangkan varietas tanaman jagung manis TALENTA tanpa persetujuan pemegang Hak Perlindungan Varietas Tanaman. Kasus tersebut juga telah dibawa ke jalur pengadilan, dan telah memperoleh Putusan pengadilan melalui Putusan Pengadilan Negeri Kabupaten Kediri Nomor 447/Pid.Sus/2019/PN Gpr tertanggal 8 Januari 2020.

Pengawasan merupakan tindakan yang sangat penting dalam mencegah terjadinya praktik-praktik kecurangan dalam kegiatan ekonomi, sehingga untuk memberikan

${ }_{18}$ Manan, A. (2013). Penemuan Hukum Oleh Hakim Dalam Praktek Hukum Acara Di Peradilan Agama. Jurnal Hukum dan Peradilan, 2(2), 189-202. DOI: http://dx.doi.org/10.25216/jhp.2.2.2013.189-202

19 Muwahid. (2017). Metode Penemuan Hukum (Rechtsvinding) oleh Hakim dalam Upaya Mewujudkan Hukum yang Responsif. The Indonesian Jurnal of Islamic Familiy Law, 7(1), 224-248. 
ruang gerak kepada instansi terkait untuk dapat melakukan pengawasan terhadap perlindungan varietas tanaman diperlukannya pengaturan terhadap pengawasan tersebut oleh pembuat undang-undang yakni dengan melakukan metode konstruksi hukum berupa metode analogi, rechtsverfijning, dan argumentum a contrario, agar tindakan pengawasan yang dilakukan oleh instansi terkait memiliki landasan yuridis yang kuat dan sah menurut hukum. Melalui pengawasan itu pula instansi terkait dapat memberikan proteksi terlebih dahulu sebelum timbul ancaman-ancaman yang dapat menghilangkan eksistensi dari varietas tanaman yang telah didaftarkan tersebut, serta merugikan masyarakat selaku konsumen produk yang memperoleh perlindungan varietas tanaman.

Apabila pengawasan terhadap varietas tanaman telah diatur secara yuridis dalam peraturan perundang-undangan, maka dapat memberikan dampak positif bagi keberadaan varietas tanaman yang telah didaftarkan. Adapun manfaat yang dapat diberikan, jika pengawasan yang dilakukan oleh instansi terkait terhadap varietas tanaman telah diatur secara yuridis dalam peraturan perundang-undangan berlaku, yaitu:

1) Mencegah terjadinya tindakan-tindakan kecurangan yang dilakukan oleh oknum-oknum yang tidak bertanggungjawab seperti penipuan, praktik monopoli, dan tindakan-tindakan lainnya yang dapat menimbulkan dampak negatif bagi perkembangan perekonomian secara nasional.

2) Menjaga eksistensi dari varietas tanaman yang telah didaftarkan dari masyarakat.

3) Melindungi varietas tanaman dari segala bentuk tindakan yang dapat mengancam keberadaan varietas tanaman itu sendiri di masyarakat.

4) Mengupayakan keberadaan varietas tanaman tetap terjaga seperti halnya pada saat varietas tanaman itu pertama kali muncul.

5) Memberikan jaminan kualitas produk kepada masyarakat selaku konsumen.

Berdasarkan uraian di atas, dapat dikatakan bahwa arti penting pengaturan aspek pengawasan terkait perlindungan varietas tanaman, yakni dapat memberikan rasa aman dan nyaman kepada seseorang yang secara sah sebagai hak milik varietas tanaman, mempertahankan penghargaan yang telah diperoleh oleh suatu varietas tanaman melalu pendaftaran, dan sebagai landasan berpijak kepada instansi terkait untuk dapat melaksanakan pengawasan terhadap perlindungan varietas tanaman. Melalui hal tersebut, maka instansi terkait mampu melakukan pengawasan dalam bentuk mencegah terjadinya tindakan kecurangan yang dilakukan oleh oknum-oknum yang tidak bertanggungjawab, menjaga eksistensi varietas tanaman dari masyarakat, melindungi varietas tanaman dari segala tindakan yang dapat mengancam keberadaan varietas tanaman, serta mengupayakan agar keberadaan varietas tanaman tetap terjaga seperti pada saat varietas tanaman itu muncul. Dengan kata lain, karakteristik dari varietas tanaman tersebut tidak berubah seiring dengan perkembangan kehidupan di masyarakat. Sehingga, melalui pengawasan yang dilakukan oleh instansi terkait secara langsung dapat memperkuat sistem perekonomian di Indonesia dalam bidang pertanian. 


\section{Kesimpulan}

Pengaturan aspek pengawasan terkait perlindungan varietas tanaman belum diatur secara yuridis dalam peraturan perundang-undangan, sehingga dapat memberikan celah kepada oknum-oknum yang tidak bertanggungjawab untuk menggunakan perlindungan varietas tanaman demi kepentingan pribadinya secara melawan hukum. Pengaturan aspek pengawasan dalam perlindungan varietas tanaman, dapat memberikan landasan kepada instansi terkait untuk melakukan pencegahan tindakantindakan kecurangan, menjaga eksistensi varietas tanaman, melindungi serta mengupayakan agar perlindungan varietas tanaman yang telah ada sebelumnya tetap terjaga sama seperti semula. Rekomendasi ditujukan kepada pembuat undangundang, diharapkan kedepannya mampu untuk membentuk peraturan yang tegas dan jelas terkait dengan aspek pengawasan terhadap varietas tanaman, yang pada intinya dimaksudkan untuk memberikan landasan yuridis yang sah kepada pihak terkait untuk melakukan pengawasan, sekaligus mendorong pihak terkait untuk mampu melakukan tindakan-tindakan pencegahan sebelum terjadinya pelanggaranpelanggaran yang dilakukan oleh oknum-oknum yang tidak bertanggungjawab terhadap suatu varietas tanaman.

\section{Ucapan Terima Kasih (Acknowledgments)}

Tidak lupa penulis mengucapkan terima kasih kepada bapak Dr. I Wayan Wiryawan, S.H., M.H. yang telah bersedia untuk turut serta sebagai penulis dalam penulisan artikel ini, sehingga membantu penulis dalam melatih serta mengembangkan pemikiran-pemikiran demi kelancaran penulisan arikel yang berkaitan dengan pengaturan bidang pengawasan dalam perlindungan varietas tanaman di Indonesia. Tidak lupa pula penulis mengucapkan terima kasih kepada orang tua yang telah memberikan dukungan baik secara langsung maupun tidak langsung, serta kepada para pihak yang telah membantu penulis melalui diskusi dan bertukar pemikiran sehingga artikel ini dapat penulis selesaikan tepat waktu. Besar harapan penulis, agar segala pemikiran yang tertuang dalam artikel ini dapat bermanfaat bagi pengembangan ilmu pengetahuan yang berkaitan dengan hukum kekayaan intelektual, khususnya mengenai perlindungan varietas tanaman.

\section{Daftar Pustaka}

\section{Buku}

Darmodiharjo, D dan Shidarta. (2014). Pokok-Pokok Filsafat Hukum. Jakarta: PT Gramedia Pustaka Utama.

Hadjon, P.M \& Djatmiati, T.S. (2016). Argumentasi Hukum. Yogyakarta: Gadjah Mada University Press.

Handoko, D. (2015). Hukum Positif mengenai Hak Kekayaan Intelektual di Indonesia. Pekanbaru: Hawa dan Ahwa.

Hidayah, K. (2018). Hukum Hak Kekayaan Intelektual. Malang: Setara Press.

\section{Jurnal}

Azrai, M. (2006). Sinergi teknologi marka molekuler dalam pemuliaan tanaman jagung. Jurnal Litbang Pertanian, 25(3), 81-89. 
Sawitri, D. A. D., \& Dharmawan, N. K. S. (2020) Perlindungan Transformasi Karya Cipta Lontar Dalam Bentuk Digitalisasi. Acta Comitas: Jurnal Hukum Kenotariatan, 5(2), 298-308., DOI: https://doi.org/10.24843/AC.2020.v05.i02.p08

Dewi, I. S., \& Purwoko, B. S. (2001). Kultur antera untuk mendukung program pemuliaan tanaman padi. Jurnal Agronomi Indonesia (Indonesian Journal of Agronomy), 29(2).

Imaniyati, N. S. (2015). Perlindungan HKI Sebagai Upaya Pemenuhan Hak Atas IPTEK, Budaya dan Seni. Media Hukum, 17(1).

Juanda, E. (2017). Konstruksi Hukum dan Metode Interpretasi Hukum. Jurnal Ilmiah Galuh Justisi, 4(2), 168-180.

Lestari, E. I., Raisah, K., \& Prabandari, A. P. (2019). Perlindungan Hukum Terhadap Varietas Tanaman Dalam Memberikan Kepastian Hukum Kepada Pemulia Tanaman. Notarius, 12(2), 972-984.

DOI: https://doi.org/10.14710/nts.v12i2.29140

Manan, A. (2013). Penemuan Hukum Oleh Hakim Dalam Praktek Hukum Acara Di Peradilan Agama. Jurnal Hukum dan Peradilan,2(2), 189-202. DOI: http://dx.doi.org/10.25216/jhp.2.2.2013.189-202

Muwahid. (2017). Metode Penemuan Hukum (Rechtsvinding) oleh Hakim dalam Upaya Mewujudkan Hukum yang Responsif. The Indonesian Jurnal of Islamic Familiy Law, 7(1), 224-248.

Nurhardianto, F. (2015). Sistem Hukum dan Posisi Hukum Indonesia. Jurnal Tapis: Jurnal Teropong Aspirasi Politik Islam,11(1), 33-44. DOI: https://doi.org/10.24042/tps.v11i1.840

Purwandoko, P. H., \& Imanullah, M. N. (2013). Perlindungan Varietas Tanaman Sebagai Salah Satu Bentuk Perlindungan Hak Ekonomi Para Pemulia Tanaman Menuju Ketahanan Pangan Nasional. Yustisia Jurnal Hukum, 2(3)., 84. DOI: https://doi.org/10.20961/yustisia.v2i3.10162

Rahmatullah, I. (2014). Perlindungan indikasi geografis dalam hak kekayaan intelektual (HKI) melalui ratifikasi perjanjian Lisabon. Jurnal Cita Hukum, 2(2). DOI: https://doi.org/10.15408/jch.v1i2.1470 .

Simanjuntak, F. (2013). Perlindungan Hukum Pada Pemberian Lisensi Bagi Pemulia Varietas Tanaman. LAW REFORM, 9(1), DOI: https://doi.org/10.14710/lr.v9i1.12433.

Soedjono, S. (2003). Aplikasi mutasi induksi dan variasi somaklonal dalam pemuliaan tanaman. Jurnal Litbang Pertanian, 22(2), 70-78.

Titawati T., Loilewen, A. F., \& Ardika, G. T. (2020). Perlindungan Hukum Bagi Pemulia Tanaman. Ganec Swara, 14(1), 499-505., DOI: 10.35327/gara.v14i1.126

\section{Peraturan Perundangan}

Undang-Undang Nomor 29 Tahun 2000 tentang Perlindungan Varietas Tanaman

Peraturan Pemerintah Nomor 13 Tahun 2004 tentang Penamaan, Pendaftaran, dan Penggunaan Varietas Turunan Esensial

Peraturan Pemerintah Nomor 14 Tahun 2004 tentang Syarat dan Tata Cara Pengalihan Perlindungan Varietas Tanaman dan Penggunaan Varietas yang Dilindungi oleh Pemerintah 